\title{
Rebuilding Our Green Infrastructure
}

$\mathrm{R}$ estoration has entered the mainstream of public life. The Deepwater Horizon disaster has brought ecological restoration to the public's attention, and there has been much talk of ecological restoration in political leaders' public statements, from local councilors to national presidents.

I have just returned from the seventh SER Europe conference in Avignon, France: "Ecological Restoration and Sustainable Development-Establishing Links Across Frontiers," where methods, restoration ecology concepts, and projects were widely demonstrated, discussed, and debated. The meeting was attended by participants from 37 countries, and more than 250 papers and posters were presented.

I was fortunate enough to attend a field trip to Mount Ventoux and the surrounding areas in the French Southern Alps. This is a site in Europe with an early history of ecological restoration. Around the mid-1800s, it was recognized that the heavy use of the mountain slopes, principally for grazing and other agricultural uses, had resulted in significant erosion and problems with sedimentation and surface water quality. Reforestation ensued, and today the area is extensively forested. Of course, some challenges remain, but this shows that ecological restoration thinking extends further back in time than many might imagine.

The New Forests, planted in the largely cleared landscape of medieval England nearly 900 years ago, were, to a certain extent, ecological restoration projects. Importantly, the rights of local people ("commoners") to use the forest are enshrined in law, and the New Forest in Hampshire contains extensive areas of lowland habitats that have been lost elsewhere-particularly valley bogs, wet heaths, dry heaths, and deciduous woodland. Nature and culture are intimately connected in this way.

As exciting was the discussion of the new biodiversity targets recently adopted by the Council of the European Union (2010), which are particularly impressive as they go beyond conservation and biodiversity to include ecosystem services and restoration:

$[\mathrm{H}]$ alting the loss of biodiversity and the degradation of ecosystem services in the EU by 2020 ,and restoring them in so far as feasible, while stepping up the EU contribution to averting global biodiversity loss. (p. 4)

Ecological Restoration Vol. 28, No. 4, 2010

ISSN 1522-4740 E-ISSN 1543-4079

C2010 by the Board of Regents of the University of Wisconsin System.
[B]y 2050 European Union biodiversity and the ecosystem services it provides—its natural capital—are protected, valued and appropriately restored for biodiversity's intrinsic value and for their essential contribution to human wellbeing and economic prosperity, and so that catastrophic changes caused by the loss of biodiversity are avoided. (p. 4)

These are ambitious but achievable targets that put ecological restoration at the heart of European policy. What's more, these extend into protecting and enhancing Europe's "green infrastructure"-essentially the "natural capital" from which ecosystem services flow. They encompass all aspects of land use, be it "wild," rural, agricultural, or urban. We still need to identify in a quantifiable way the functional relationships between the amount and type of biodiversity (at a number of scales) and the outcomes for regulation, production, and cultural services. Many of the relationships between biodiversity and ecosystem function, and therefore services, are likely to be nonlinear-small changes at the margin in biodiversity may result in irreversible crossing of thresholds, leading to large drops in service flows and directly impacting stability, resilience, and vulnerability of ecosystems, and therefore society. However, as amply demonstrated at the Avignon conference, we have the tools and experience to embark on the renewal and restoration of our green infrastructure-let's get on with it!

I'd like to finish on a personal note to record my thanks to Mrill Ingram for the sterling work that she has carried out during her tenure as Editor of Ecological Restoration; I shall miss working with her and wish her the very best for her new role in researching the collaborations between scientists and artists. At the same time, I warmly welcome Steven N. Handel as our new Editor. Steven organized the SER annual conference at Rutgers in 1996 and has extensive experience in restoration research, teaching, and practice, particularly in urban and periurban environments. I am sure that he will bring continued success to the journal.

\section{Jim Harris \\ Chair \\ Society for Ecological Restoration}

\section{Reference}

Council of the European Union (Environment). 2010. Biodiversity: Post-2010; EU and global vision and targets and international ABS regime, Council conclusions. Annex 7536/10, 15 March 2010. register.consilium.europa.eu/pdf/ en/10/st07/st07536.en10.pdf 